\title{
Production of mesenchymal stromal/stem cells according to good manufacturing practices: a review
}

Luc Sensebé ${ }^{1,2^{*}}$, Mélanie Gadelorge $e^{1,2}$ and Sandrine Fleury-Cappellesso ${ }^{1,2}$

\begin{abstract}
Because of their multi/pluripotency and immunosuppressive properties, mesenchymal stem/stromal cells (MSCs) are important tools for treating immune disorders and for tissue repair. The increasing use of MSCs, their definition as advanced-therapy medicinal products in European regulations, and the US Food and Drug Administration requirements for their production and use imply the use of production processes that should be in accordance with Good Manufacturing Practices (GMPs). Complying with GMPs requires precisely defining the production process (es) as well as the multiple criteria required for a quality final product. Such variables include the environment, staff training and qualification, and controls. Developing processes based on well-defined or completely defined media and operating in closed systems or bioreactors is important and will increase safety and reproducibility. One of the most challenging issues remains implementation of relevant and reproducible controls for safety and efficacy. A linking of researchers, research and development teams, producers, and clinicians is mandatory to achieve GMP-compliant processes with relevant controls for producing well-defined, safe, and efficient MSCs.
\end{abstract}

\section{Introduction}

Producing cells according to Good Manufacturing Practices (GMPs) is a global challenge for the production of all cells for use in humans, specifically mesenchymal stem/stroma cells (MSCs), one of the most promising tools in cellular therapy and regenerative medicine. MSCs with a mesodermic origin were first described by Alexander Friedenstein and colleagues in the 1960s and 1970s [1] as non-hematopoietic bone marrow (BM) cells that adhered to plastic and that could develop into colonies with a fibroblastic appearance. The cells were first named colonyforming unit-fibroblasts (CFU-Fs). They could differentiate into bone, cartilage, and a hematopoietic microenvironment. The first use in a clinical setting was reported in 1995, without side effects [2]. Later, MSCs were described as stem cells of skeletal tissues (for example, bone and cartilage) [3], and one of the first clinical uses was in

\footnotetext{
* Correspondence: luc.sensebe@efs.sante.fr

'UMR5273 CNRS, UPS, EFS-INSERM U1031, STROMALab, BP 84 225, 31432, Toulouse, France

EFS Pyrénées-Méditerranée, Av. de Grande Bretagne, BP 3210-31027, Toulouse Cedex 3, France
}

combination with biomaterials to repair long-bone fractures, which demonstrated good efficacy [4].

Since 2000, the MSC field has moved rapidly with the demonstration that ex vivo-grown MSCs had immunosuppressive properties after treatment with inflammatory cytokines such as IFN- $\gamma$, IL-1, or TNF- $\alpha$ [5] and acted on all effectors of innate and adaptive immunity [6]. These immunosuppressive properties were first used in transplanting hematopoietic stem cells to treat drugresistant graft-versus-host disease [7] and were found to be useful for improving organ transplantation by decreasing rejection [8]. Moreover, MSCs have trophic effects mediated by numerous growth factors and the cytokines they produce [9].

The first emerging cells of the MSC type were found to originate from the neural crest and not the mesoderm [10], and cells with the same features as BM MSCs were found in almost all tissues in the fetus, neonate, and adult [11]. An international expert panel [12] described the common minimal criteria for cells in the MSC category: cells adhering to plastic; able to form CFU-Fs; expressing CD90, CD73, and CD105 without the hematopoietic molecules 
CD45, CD34, and HLA-DR; and able to differentiate via osteoblastic, chondrocytic, and adipocytic pathways. These main characteristics apply to cultured BM MSCs, but some differences might appear to be related to the tissue of origin. Examples are adipose tissue (AT)-derived MSC expression of CD34 and CD54 [13]. Finally, phenotype and function studies revealed that MSCs from different tissues are not exactly equivalent [14]. In addition, MSCs could express HLA-DR after stimulation with IFN- $\gamma$ or spontaneously, depending on culture conditions [15,16]. Although MSCs are first described in BM, BM MSCs producing hematopoietic microenvironment and presenting selfrenewal [17], a unique MSC entity over all tissues is debated [14]. Cells referred to as MSCs originating from various tissues are now used in clinical trials.

Whatever the MSC source, the safety, efficacy, and reproducibility of MSC production and compliance with GMPs must be ensured. Most of the problems refer to processes: open systems versus bioreactors, reagents and particularly media used, and controls ensuring safety and efficacy of the final product. However, some other important issues should be addressed: donor eligibility and screening, facilities, environmental controls, and storage. We review these questions with specific emphasis on processes and controls that largely remain difficult to fix and that, for some, seem poorly relevant.

\section{Good manufacturing practice and mesenchymal stem/stromal cell production}

In Europe, MSCs are somatic cell therapy products, referred to as advanced-therapy medicinal products (ATMPs), and are under European Regulation No. 1394/2007. Regulation 1394/2007 contains rules for authorization, supervision, and technical requirements regarding the summary of product characteristics, labeling, and the package leaflet of ATMPs, which are prepared following industrial methods and in academic institutions. The production and delivery of MSCs should be in accordance with European GMPs (Euralex).

In the US, the production of MSCs, like that of any other human cell- and tissue-based products (HCT/Ps), must comply with Current Good Tissue Practice requirements, under the Code of Federal Regulations (CFR, FDA for facilities (Part 1271.190a and b), environmental control (Part 1271.195a), equipment (Part 1271.200a), supplies and reagents (Part 1271.210a and b), recovery (Part 1271.215), processing and process controls (Part 1271.220), labeling controls (Part 1271.250a and b), storage (Part 1271.260a-d), receipt, pre-distribution shipment, and distribution of an HCT/P (Part 1271.265a-d), and donor eligibility determination, screening, and testing (Parts 1271.50, 1271.75, 1271.80, and 1271.85)).

The translation of research-based protocols into procedures for large-scale production of clinical-grade
MSCs complying with GMPs requires a deep analysis of all critical aspects [18]. For MSCs, as for other cell cultures, the facilities should be in accordance with the CFR Parts 1271.190a and b and European regulations. For example, an open system for culturing or processing cells requires use of a class A cabinet operated in a class $B$ room. The environment must be qualified and controlled to prove that the levels are achieved and maintained. Also, supplies and reagents, recovery, and labeling controls as well as storage, receipt, predistribution shipment, and distribution of materials are the same as for culture of other NCT/Ps. However, producing MSCs involves several specific conditions.

\section{Donor and cell sources}

- For MSCs, the donor eligibility, mainly age and viral testing, is based on the same criteria as for other cell- and tissue-based products. However, apart from microbiological safety, evaluation criteria of the normality or potency of donor MSCs are lacking; therefore, determining who will be a good MSC donor is still difficult. Age could be an important criterion: BM of children may have a higher level of progenitors (CFU-Fs) [19], and age could be directly linked to decreased in vitro proliferation and multipotency [20]. Although there are no specific regulatory requirements, the main problem for donor selection remains the risk of abnormalities with MSCs, which is difficult to assess. This point is of particular importance when producing large batches of MSCs, from one or a few donors, for allogeneic uses in multiple recipients.

- As previously reported, cells of the MSC type are present in all tissues [11]. Thus, many sources of MSCs have been described and used. The main candidates for clinical applications are BM, AT, and fetal or neonate tissue (for example, placenta, amniotic membrane, and Wharton's jelly). BM and AT have been the most used sources; they are easy to collect by standardized procedures. MSCs are more abundant in AT than BM. Despite a standardized collection technique, a short time between collection and processing, and a high volume and cell content of collected blood [21], obtaining MSCs from cord blood on a regular basis is difficult with variable cell yield and viability. Neonate or fetal sources are being investigated as sources of more primitive MSCs.

- After harvesting and processing of cells (for example, AT dissociation by collagenase), MSCs could be seeded as a crude population or after MSC enrichment with immunomagnetic devices or fluorescence-activated cell sorting (FACS) with 
known MSC-expressed antigens (Ags). One of the most used Ags is STRO-1, whose use leads to large enrichment of CFU-Fs and STRO- $1^{+} / \mathrm{CD} 106^{+}$cells representing a highly purified MSC population [22]. Other Ags, such as $\alpha 1$ integrin subunit (CD49a) or CD200 $[23,24]$ or CD271 (low-affinity nerve growth factor receptor) [25], can be used. Regardless of cell source, cell population, fractionated status, or separation by density gradient, plastic adherence remains the main step to isolate MSC populations. Although the use of raw material (for example, unfractionated BM or stromal vascular fraction of fat) could deliver some immunological priming [16], the most convenient and efficient way is to use unfractionated starting material.

- Because MSCs are adherent cells, cell-plating density is one of the main critical conditions for optimal expansion rate and maintenance of MSC functions. Use of low or very low plating density could maintain a high proliferation rate and multipotentiality [26]. After the first culture phase, plating densities of 1,000 to 4,000 cells $/ \mathrm{cm}^{2}$ seem reasonable and allow a high number of final MSCs [27]. Sequential passages may affect the quality of cultured MSCs, with progressive senescence, slowed proliferation rate, and cells progressively experiencing loss of multipotentiality [28]. Thus, limiting the number of population doublings to less than 20 seems appropriate [16].

\section{Production processes Media}

From the beginning of the production of MSCs, an appropriate simple medium allowing for ex vivo growth of MSCs is $\alpha$-minimal essential medium or Dulbecco's modified Eagle's medium supplemented with $10 \%$ fetal calf serum (FCS). With this simple medium, MSCs can be grown but with a long doubling time (more than 1 month) to achieve useful quantities. Several cytokines and growth factors - for example, platelet-derived growth factor (PDGF) and fibroblast growth factor 2 (FGF2) - are active in in vitro MSC growth. The addition of cytokines to MSC culture improves the process; specifically, the use of FGF2 at a low concentration $(1 \mathrm{ng} / \mathrm{mL})$ can result in a large number of MSCs in 2 to 3 weeks [16]. These media, though simple, are based on a xenogeneic source of growth factors (FCS) that could transmit unexpected or emerging diseases. Therefore, new developments are based on supplementation with human blood-derived products secured by serologic and nuclear acid testing of blood-transmitted viruses (for example, HIV and hepatitis $\mathrm{C}$ virus) with, eventually, a supplemental step of virus inactivation. The most reliable and most used human supplementation product is platelet lysate (PL), consisting of plasma enriched by platelet growth factors released by freezingthawing cycles [29]. Large quantities of MSCs from diverse sources (BM, AT, and so on) can be grown with concentrations from $2 \%$ to $8 \%$ PL [30]. The effects of PL are principally related to the presence of large quantities of cytokines and growth factors such as PDGF and FGF2 [31].

The media seem to be equivalent for producing large amounts of MSCs but are not equivalent in terms of time of culture and functions [32]. Indeed, medium used for producing cells could affect the behavior of the final product, so the safety and efficacy of MSCs produced by different media should be carefully tested and documented; for example, BM MSCs grown in medium supplemented with PL commit to an osteoblastic pathway [33]. The goal is the development of completely defined media that lack any biological products from animal or human origins. Different serum-free media based on cocktails of growth factors (for example, FGF2, PDGF, and transforming growth factor-beta) can maintain the main phenotypic and functional characteristics of cultured MSCs [34] but are still used for research purposes and require upgrading for clinical uses. The remaining problem with the use of completely defined media is the attachment of cells, which implies the use of a specific protein to ensure the first cell attachment.

\section{Bioreactors/closed systems}

As stated in GMPs (that is, Appendix 1 of the current European GMP regulations), MSC production (like production of any cellular products) requires aseptic conditions and their validation. Therefore, the development and use of closed automated devices are an important step facilitating MSC expansion with GMPs. A first step is the use of multilayer systems - such as CellStacks (Corning, Corning, NY, USA) or Cellfactory (Nunc, part of Thermo Fisher Scientific Inc., Waltham, MA, USA) that could be stacked in incubators. These devices allow for the safe use of a wide surface area and easy production of hundreds of millions to 1 billion pure MSCs in 2 to 3 weeks [16]. However, in terms of GMP requirements, these processes are not fully closed and require a class A cabinet for each manipulation. For simpler and safer processes, a fully closed and automated bioreactor must be used. The main criteria for growing MSCs in bioreactors are a large ratio of surface area to volume, a closed system, automated inoculation and harvesting, and automated control of culture parameters. Different designs of bioreactors - parallel-plate, hollow-fiber, or micro-fluidic [35] - could help improve these criteria. Multilayered systems could be coupled with automatic devices allowing medium circulation and helping with medium replacement, such as the system from ATMI 
(Bloomington, MN, USA). The company Terumo (Somerset, NJ, USA) has developed a fully automated bioreactor based on hollow-fiber technology that can allow for a large expansion of MSCs in a GMP-compliant system [36]. Linked with animal- or serum-free media, these technologies can provide the optimal tools for delivering MSCs of clinical grade that comply with GMPs. Moreover, bioreactors could help manage environmental conditions that change or improve the behavior of MSCs; for example, supplying continuous low oxygen tension improves the growth and genetic stability of MSCs [37], and three-dimensional culture increases anti-inflammatory properties [38]. Finally, the use of bioreactors performing entire processes in closed systems could allow for the production of MSCs in a class $\mathrm{C}$ or $\mathrm{D}$ room and not a class $\mathrm{A}$ cabinet in a class $\mathrm{B}$ room.

\section{Controls of ex vivo-expanded mesenchymal stem/ stromal cells}

One of the main requirements for MSC production is that controls give relevant information on the safety and efficacy of the released products. Such controls should allow for a determination of the identity and purity of cell products and, if applied to the release of fresh product, should be reproducible and fast. These requirements are challenging and not yet fully achieved.

\section{Controls for safety}

As for all ex vivo-expanded cells that do not undergo sterilization processes or filtration, the sterility of the final MSC product must nevertheless be guaranteed. Pharmacopeia (for example, European Pharmacopeia) can be used for this purpose. Lack of classic bacteria and mycoplasma contamination must be documented, and the presence of endotoxins must be tested.

Because MSCs are expanded ex vivo cells, sometimes for a long period with a high number of population doublings, they can undergo senescence and some can undergo genetic instability. Recently, important concerns have been raised regarding the risk of transformation after long-term culture that are related to some cells escaping the senescence program. Replicative senescence arises through well-known mechanisms such as telomere shortening and activation of the pRB pathway through the INK4a/ARF locus encoding p16ink $4 a$ and p19ink4a as well as the p53 pathway [39]. Senescence and transformation are tightly linked [40]; cells becoming senescent could transform after a transient senescence crisis or abrogation of senescence mechanisms by a reincrease of telomere length or repression of p16ink $4 a$ and p53 activity [41]. During culture, senescence of MSCs induces growth arrest with normal telomere shortening, decreased differentiation with predominant osteogenic potential, downregulation of genes related to tumorigenesis such as $m y c$ and ras, and upregulation of some gene clusters and some microRNAs [42]. These changes during senescence appear to be continuous. A few studies reported that cultured human MSCs could show chromosome abnormalities and transform [43,44]. However, these results were recently retracted because they were based on a contaminated exogenous cancer cell line [45,46]. Using karyotype and comparative genomic hybridization (CGH) array, other authors showed a genetic stability of MSCs during culture [47]. Recently, we demonstrated that clinical-grade cultured human MSCs could undergo senescence and never transform, with or without aneuploidy, mainly duplication of chromosomes 5 and 8 [16]. Finally, a study showed that human adult MSCs had a $4 \%$ probability of acquiring chromosomal abnormalities that are lineage-specific [48]. However, misleading interpretations have minimized these conclusions [49]. Moreover, since the first clinical trial in humans [2], tumors have never been reported with application of MSCs.

To avoid the main risks during the use of MSCs, the genetic stability of MSCs expanded by GMP processes must be tested. Different assays could be used for testing. The oldest one is the karyotype assay, which has problems. First, karyotype testing is not really sensitive, allowing the analysis of 30 to 50 cells in metaphase on millions or billions of produced cells. Second, in the context of cell production far from the area of diagnosis and residual disease assessment, the relevance of karyotype is not established. To increase sensitivity, fluorescence in situ hybridization (FISH) can be used to easily increase the sensitivity (for 200 to 1,000 analyzed cells) but is not really sensitive in terms of the number of cells in the final product. Also, the technique is difficult, requires knowledge of the target to search for, and lacks relevant final information. CGH array is more sensitive than karyotype assay and FISH and can be used to detect unknown abnormalities, but some limitations persist. Particularly, a minimum of $20 \%$ to $25 \%$ of cells must present the same abnormalities. The real question is how to predict something that has never happened to date. We need a new approach to controls, one that focuses on the molecular events involved in transformation and senescence. Recently, a group of experts and persons from European Regulatory Authorities proposed a pragmatic statement: the number of population doublings should be minimal, and conventional karyotype combined with CGH array or FISH are only necessary when recurrent abnormalities are found [50].

\section{Controls of identity and efficacy}

Controls of identity are simple and are based on FACS analysis of surface Ags. Most of these controls are in the consensus paper by an international panel of experts 
from the International Society for Cellular Therapy [12]. The minimal panel of Ags comprises positive Ags (CD90, CD73, and CD105) and negative Ags (CD45, CD34 (for BM MSCs only), and HLA-DR). At this step, viability should be tested by FACS or a simple method such as trypan blue dye exclusion.

Efficacy is based in large part on previous in vitro and in vivo experiments carried out in animals during the preclinical phase of process development. For product release, the implementation of relevant potency assays is challenging. For example, for the capacity of differentiation, MSCs can commit to an osteoblastic pathway; there are different ways to look at the osteoblastic engagement of MSCs in vitro, but results of many tests could be prone to artifacts. Before choosing assays, one must carefully demonstrate that the process can give relevant results by parallel in vivo testing. MSCs are now widely used for their anti-inflammatory or immunosuppressive properties; the immunosuppressive capacity of produced MSCs must be tested in vitro. Tests could be standardized and validated as demonstrated by different teams working together in an international consortium [6].

\section{Conclusions}

The MSC field is reaching maturity. Numerous phase 2 trials are in progress, but few phase 3 trials have been implemented. All of the regulatory requirements for safety and efficacy of MSCs used or intended to be used imply full compliance with GMPs. We now have different media, tools, and devices that help in compliance with GMP, and different public institutions and private companies have adequate rooms for working in the right environment. However, the most challenging point remains the definition and implementation of relevant controls for safety, particularly for testing genetic stability, and for efficacy. To be able to develop such control requires close collaboration among research and development teams, clinicians performing clinical trials, and industry.

\section{Abbreviations \\ Ag: Antigen; AT: Adipose tissue; ATMP: Advanced-therapy medicinal product; BM: Bone marrow; CFR: Code of Federal Regulations; CFU-F: Colony-forming unit-fibroblast; CGH: Comparative genomic hybridization; FACS: Fluorescence- activated cell sorting; FCS: Fetal calf serum; FGF2: Fibroblast growth factor 2; FISH: Fluorescence in situ hybridization; GMP: Good Manufacturing Practice; HCT/P: Human cell- and tissue-based product; IFN: Interferon; IL: Interleukin; MSC: Mesenchymal stem/stromal cell; PDGF: Platelet-derived growth factor; PL: Platelet lysate; TNF: Tumor necrosis factor.}

\section{Competing interests}

The authors declare that they do not have any competing interests.

\section{Acknowledgments}

This work was supported by grants from the 7th Framework Program of the European Commission: CASCADE (FP7-HEALTH-233236) and REBORNE (FP7HEALTH- 241879); by grants from Agence Nationale pour la Recherche: SAFE
(ANR-2011-RPIB-01201), and the Infrastructure Program: ACELLFRANCE (ANR11-INSB-005); and by a grant from Région Midi-Pyrénées (NOMASEC).

Published: 7 June 2013

\section{References}

1. Friedenstein AJ, Gorskaja JF, Kulagina NN: Fibroblast precursors in normal and irradiated mouse hematopoietic organs. Exp Hematol 1976, 4:267-274.

2. Lazarus HM, Haynesworth SE, Gerson SL, Rosenthal NS, Caplan Al: Ex vivo expansion and subsequent infusion of human bone marrow-derived stromal progenitor cells (mesenchymal progenitor cells): implications for therapeutic use. Bone Marrow Transplant 1995, 16:557-564.

3. Caplan Al: The mesengenic process. Clin Plast Surg 1994, 21:429-435.

4. Quarto R, Mastrogiacomo M, Cancedda R, Kupetov SM, Mukhachev V, Lavroukov A, Kon E, Marcacci M: Repair of large bone defects with the use of autologous bone marrow stromal cells. N Engl J Med 2001, 344:385-386.

5. Krampera M, Cosmi L, Angeli R, Pasini A, Liotta F, Andreini A, Santarlasci V, Mazzinghi B, Pizzolo G, Vinante F, Romagnani P, Maggi E, Romagnani S, Annunziato F: Role of the IFN- $\gamma$ in the immunomodulatory activity of human mesenchymal stem cells. Stem Cells 2005, 24:386-398.

6. Menard C, Pacelli L, Bassi G, Dulong J, Bifari F, Bezier I, Zanoncello J, Ricciardi M, Latour M, Bourin P, Schrezenmeier H, Sensebé L, Tarte K, Krampera M: Clinical-grade mesenchymal stromal cells produced under various GMP processes differ in their immunomodulatory properties: standardization of immune quality controls. Stem Cells Dev 2013. Jan 22 [Epub ahead of print].

7. Le Blanc K, Rasmusson I, Sundberg B, Gotherstrom C, Hassan M, Uzunel M, Ringden O: Treatment of severe acute graft-versus-host disease with third party haploidentical mesenchymal stem cells. Lancet 2004, 363:1439-1441.

8. Tan J, Wu W, Xu X, Liao L, Zheng F, Messinger S, Sun X, Chen J, Yang S, Cai J, Gao X, Pileggi A, Ricordi C: Induction therapy with autologous mesenchymal stem cells in living-related kidney transplants: a randomized controlled trial. JAMA 2012, 307:1169-1177.

9. Phinney DG, Prockop DJ: Concise review: mesenchymal stem/multipotent stromal cells: the state of transdifferentiation and modes of tissue repaircurrent views. Stem Cells 2007, 25:2896-2902.

10. Takashima Y, Era T, Nakao K, Kondo S, Kasuga M, Smith AG, Nishikawa SI: Neuroepithelial cells supply an initial transient wave of MSC differentiation. Cell 2007, 129:1377-1388.

11. Crisan M, Yap S, Casteilla L, Chen CW, Corselli M, Park TS, Andriolo G, Sun B, Zheng B, Zhang L, Norotte C, Teng PN, Traas J, Schugar R, Deasy BM, Badylak S, Bühring HJ, Giacobino JP, Lazzari L, Huard J, Peault B: A perivascular origin for mesenchymal stem cells in multiple human organs. Cell Stem Cell 2008, 3:301-313.

12. Dominici M, Le Blanc K, Mueller I, Slaper-Cortenbach I, Marini F, Krause D, Deans R, Keating A, Prockop DJ, Horwitz E: Minimal criteria for defining multipotent mesenchymal stromal cells. The International Society for Cellular Therapy position statement. Cytotherapy 2006, 8:315-317.

13. De Ugarte DA, Morizono K, Elbarbary A, Alfonso Z, Zuk PA, Zhu M, Dragoo $J$, Ashijan P, Thomas B, Benhaim P, Chen I, Frazer J, Hedrick MH: Comparison of multilineage cells from human adipose tissue and bone marrow. Cells Tissues Organs 2003, 174:101-109.

14. Phinney DG, Sensebé L: Mesenchymal stromal cells: misconceptions and evolving concepts. Cytotherapy 2013, 15:140-145.

15. Sotiropoulou PA, Perez SA, Gritzapis AD, Baxevanis CN, Papamichail M: Interactions between human mesenchymal stem cells and natural killer cells. Stem Cells 2006, 24:74-85.

16. Tarte K, Gaillard J, Lataillade JJ, Fouillard L, Becker M, Mossafa H, Tchirkov A, Rouard H, Henry C, Splingard M, Dulong J, Monnier D, Gourmelon P, Gorin NC, Sensebé L, Société Française de Greffe de Moelle et Thérapie Cellulaire: Clinical-grade production of human mesenchymal stromal cells: occurrence of aneuploidy without transformation. Blood 2010, 115:1549-1553.

17. Sacchetti B, Funari A, Michienzi S, Di Cesare S, Piersanti S, Saggio I, Tagliafico E, Ferrari S, Gehron Robey P, Riminucci M, Bianco P: Self-renewing osteoprogenitors in bone marrow sinusoids can organize a hematopoietic microenvironment. Cell 2007, 131:324-336. 
18. Sensebe L, Bourin P, Tarte K: Good manufacturing practices production of mesenchymal stem/stromal cells. Hum Gene Ther 2011, 22:19-26.

19. Baxter MA, Wynn RF, Jowitt SN, Wraith JE, Fairbairn L, Bellantuono I: Study of telomere length reveals rapid aging of human marrow stromal cells following in vitro expansion. Stem Cells 2004, 22:675-682.

20. Stolzing A, Jones E, McGonagle D, Scutt A: Age-related changes in human bone marrow derived mesenchymal stem cells: consequences for cell therapies. Mech Ageing Dev 2008, 129:163-173.

21. Bieback K, Kern S, Klüter H, Eichler H: Critical parameters for the isolation of mesenchymal stem cells from umbilical cord blood. Stem Cells 2004, 22:625-634.

22. Gronthos S, Zannettino AC, Hay SJ, Shi S, Graves SE, Kortesidis A, Simmons $P J:$ Molecular and cellular characterisation of highly purified stromal cells derived from human bone marrow. J Cell Sci 2003, 116:1827-1835.

23. Deschaseaux F, Charbord P: Human marrow stromal precursors are alpha 1 integrin subunit-positive. J Cell Physiol 2000, 184:319-325.

24. Delorme B, Ringe J, Pontikoglou C, Gaillard J, Langonné A, Sensebé L, Noël $D$, Jorgensen C, Häupl T, Charbord P: Specific lineage-priming of bone marrow mesenchymal stem cells provides the molecular framework for their plasticity. Stem Cells 2009, 27:1142-1151.

25. Quirici N, Soligo D, Bossolasco P, Servida F, Lumini C, Deluiliers GL: Isolation of bone marrow mesenchymal stem cells by anti-nerve growth factor receptor antibodies. Exp Hemato/ 2002, 30:783-791.

26. Colter DC, Sekiya I, Prockop DJ: Identification of a subpopulation of rapidly self-renewing and multipotential adult stem cells in colonies of human marrow stromal cells. Proc Natl Acad Sci U S A 2001, 98:7841-7845.

27. Sekiya I, Larson BL, Smith JR, Pochampally R, Cui JG, Prockop DJ: Expansion of human adult stem cells from bone marrow stroma: conditions that maximize the yields of early progenitors and evaluate their quality. Stem Cells 2002, 20:530-541.

28. Banfi A, Muraglia A, Dozin B, Mastrogiacomo M, Cancedda R, Quarto R: Proliferation kinetics and differentiation potential of ex vivo expanded human bone marrow stromal cells: implications for their use in cell therapy. Exp Hematol 2000, 28:707-715.

29. Doucet C, Ernou I, Zhang Y, Llense JR, Begot L, Holy X, Lataillade JJ: Platelet lysates promote mesenchymal stem cell expansion: a safety substitute for animal serum in cell-based therapy applications. J Cell Physiol 2005, 205:228-236.

30. Fekete N, Gadelorge M, Fürst D, Maurer C, Dausend J, Fleury-Cappellesso S, Mailänder V, Lotfi R, Ignatius A, Sensebé L, Bourin P, Schrezenmeier $H_{\text {, }}$ Rojewski MT: Platelet lysate from whole blood-derived pooled platelet concentrates and apheresis-derived platelet concentrates for the isolation and expansion of human bone marrow mesenchymal stromal cells: production process, content and identification of active components. Cytotherapy 2012, 14:540-554.

31. Fekete $N$, Rojewski MT, Fürst D, Kreja L, Ignatius A, Dausend J, Schrezenmeier H: GMP-compliant isolation and large-scale expansion of bone marrow-derived MSC. PLoS One 2012, 7:e43255.

32. Bouacida A, Rosset P, Trichet V, Guilloton F, Espagnolle N, Cordonier T, Heymann D, Layrolle P, Sensébé L, Deschaseaux F: Pericyte-like progenitors show high immaturity and engraftment potential as compared with mesenchymal stem cells. PLOS One 2012, 7:e48648.

33. Kasten $P$, Vogel J, Beyen I, Weiss $S$, Niemeyer $P$, Leo A, Lüginbuhl R: Effect of platelet-rich plasma on the in vitro proliferation and osteogenic differentiation of human mesenchymal stem cells on distinct calcium phosphate scaffolds: the specific surface area makes a difference. J Biomater Appl 2008, 23:169-188

34. Chase LG, Lakshmipathy U, Solchaga LA, Rao MS, Vemuri MC: A novel serum-free medium for the expansion of human mesenchymal stem cells. Stem Cell Res Ther 2010, 1:8

35. Godara P, McFarland CD, Nordon RE: Design of bioreactors for mesenchymal stem cell tissue engineering. J Chem Technol Biotechnol 2010, 83:408-420.

36. Rojewski MT, Fekete N, Baila S, Nguyen K, Fürst D, Antwiler D, Dausend J, Kreja L, Ignatius A, Sensebé L, Schrezenmeier H: GMP-compliant isolation and expansion of bone marrow-derived MSCs in the closed, automated device Quantum Cell Expansion system. Cell Transplant 2012. Oct 25 [Epub ahead of print].

37. Estrada JC, Albo C, Benguira A, Dopazo A, Lopez-Romero P, CarreraQuintanar L, Roche E, Clemente EP, Enriquez JA, Bernad A, Samper E: Culture of human mesenchymal stem cells at low oxygen tension improves growth and genetic stability by activating glycolysis. Cell Death Differ 2012, 19:743-755.

38. Bartosh TJ, Ylöstalo JH, Mohammadipoor A, Bazhanov N, Coble K, Claypool K, Lee $\mathrm{RH}$, Choi H, Prockop DJ: Aggregation of human mesenchymal stromal cells (MSCs) into 3D spheroids enhances their inflammatory properties. Proc Natl Acad Sci U S A 2010, 107:13724-13729.

39. Krishnamurthy J, Torrice C, Ramsey MR, Kovalev Gl, Al-Regaiey K, Su L, Sharpless NE: Ink4a/Arf expression is a biomarker of aging. J Clin Invest 2004, 114:1299-1307.

40. Campisi J, d'Adda di Fagagna F: Cellular senescence: when bad things happen to good cells. Nat Rev Mol Cell Biol 2007, 8:729-740.

41. Serakinci N, Guldberg P, Burns JS, Abdallah B, Schrødder H, Jensen T, Kassem M: Adult human mesenchymal stem cell as a target for neoplastic transformation. Oncogene 2004, 23:5095-5098.

42. Wagner W, Horn P, Castoldi M, Diehlmann A, Bork S, Saffrich R, Benes V, Blake J, Pfister S, Eckstein V, Ho AD: Replicative senescence of mesenchymal stem cells: a continuous and organized process. PLoS One 2008, 3:1-12.

43. Rubio D, Garcia-Castro J, Martın MC, de la Fuente R, Cigudosa JC, Lloyd AC, Bernad A: Spontaneous human adult stem cell transformation. Cancer Res 2005, 65:3035-3039.

44. Røsland GV, Svendsen A, Torsvik A, Sobala E, McCormack E, Immervoll H, Mysliwietz J, Tonn JC, Goldbrunner R, Lønning PE, Bjerkvig R, Schichor C: Long-term cultures of bone marrow-derived human mesenchymal stem cells frequently undergo spontaneous malignant transformation. Cancer Res 2009, 69:5331-5339.

45. Garcia S, Martin MC, de la Fuente R, Cigudosa JC, Garcia-Castro J, Bernad A: Pitfalls in spontaneous in vitro transformation of human mesenchymal stem cells. Exp Cell Res 2010, 316:1648-1650.

46. Torsvik A, Røsland GV, Svendsen A, Molven A, Immervoll H, McCormack E, Lønning PE, Primon M, Sobala E, Tonn JC, Goldbrunner R, Schichor C, Mysliwietz J, Lah TT, Motaln H, Knappskog S, Bjerkvig R: Spontaneous malignant transformation of human mesenchymal stem cells reflects cross-contamination: putting the research field on track. Cancer Res 2010, 70:6393-6396.

47. Bernardo ME, Zaffaroni N, Novara F, Cometa AM, Avanzini MA, Moretta A, Montagna D, Maccario R, Villa R, Daidone MG, Zuffardi O, Locatelli F: Human bone marrow derived mesenchymal stem cells do not undergo transformation after long-term in vitro culture and do not exhibit telomere maintenance mechanisms. Cancer Res 2007, 67:9142-9149.

48. Ben-David U, Mayshar Y, Benvenisty N: Large-scale analysis reveals acquisition of lineage-specific chromosomal aberrations in human adult stem cells. Cell Stem Cell 2011, 9:97-102

49. Sensebé L, Tarte K, Galipeau J, Krampera M, Martin I, Phinney DG, Shi Y: Limited acquisition of chromosomal aberrations in human adult mesenchymal stromal cells. Cell Stem Cell 2012, 10:9-10.

50. Barkholt L, Flory E, Jekerle V, Lucas-Samuel S, Ahnert P, Bisset L, Büscher D, Fibbe W, Foussat A, Kwa M, Lantz O, Mačiulaitis R, Palomäki T, Schneider CK, Sensebé L, Tachdjian G, Tarte K, Tosca L, Salmikangas P: Risk of tumorigenicity in mesenchymal stem cell-based therapies: bridging scientific observations and regulatory viewpoints. Cytotherapy 2013.

\section{doi:10.1186/scrt217}

Cite this article as: Sensebé et al:: Production of mesenchymal stromal/ stem cells according to good manufacturing practices: a review. Stem Cell Research \& Therapy 2013 4:66. 